\title{
US budget yields scant research rises
}

\section{WASHINGTON DC}

KeyUS science agencies held on to slim gains this month as Congress approved next year's budget. But they may lose these rises and more in an across-the-board 2006 spending cut to help pay for hurricane relief in the southern United States and for the ongoing war in Iraq.

Lawmakers base the budget on what the president requests in February of each year (see Nature 433, 559-560; 2005), but they have the authority to increase or cut funding and to specify how dollars will be spent.

The National Science Foundation has done relatively well. Last year, the agency's budget was cut by $3 \%$, but this year it was restored by the same amount, to US $\$ 5.6$ billion, with $\$ 4.2$ billion for research (see graph). Given the tight fiscal environment, this was a reasonable achievement, says Samuel Rankin, who chairs a lobby group, the Coalition for National Science

\section{US RESEARCH BUDGET 2006}

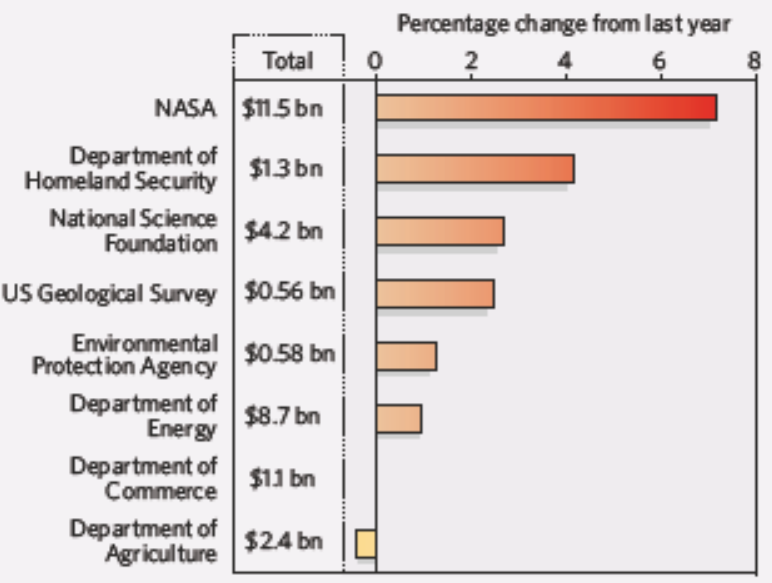

of $7.3 \%$ to keep the early development of launchers and a crew vehicle for lunar expeditions on track. A shuttle mission to repair the Hubble Space Telescope is still in the picture. And lawmakers added money for several projects that the White House had shortchanged, including the Space Interferometry Mission to search for planets around other stars and an Earth-science mission known as Glory.

Still, the chairman of the House Committee on Science, Sherwood Boehlert (Republican, New York), warns of trouble ahead as NASA gears up to send astronauts back to the Moon. "A renaissance costs Funding. "Under the circumstances, I'm quite pleased, he says.

NASA also did fairly well. Congress gave the space agency $\$ 16.4$ billion - nearly as much as the president asked for and $1.3 \%$ more than last year. The research budget gets a boost money, and I don't see any Medicis waiting in the wings to underwrite NASA, he said in a 3 November hearing. "There is simply not enough money in NASA's budget to carry out all the tasks it is undertaking on the current schedule.

\section{Small conferences pay their way}

\section{SILVERTHORNE, COLORADO}

The time and money spent attending small scientific meetings is more than paid back throughaccelerated research, suggests a survey by a conference organizer.

"The presumption is that meetings are beneficial, but the actualdata to say that something positive happens are pretty scarce," says James Aiken, president of Keystone Symposia, the non-profit meetings organization in Silverthorne, Colorado, that carried out the survey.

Researchers who attended Keystone symposia on molecular and cell biology held during 2004 and 2005 later savedsix weeks of research time and US\$6,000 in funding, according to median figures from the survey. The data represent a rare attempt to quantify just how effectively small meetings spur research.
The survey included only Keystone's own meetings, an admittedly transparent attempt to justify their worth. But independent scientists and organiz ations say that the find ings could apply to other conferences as well.

"Itquantifies something that we've always believed," says Howard Garrison, director of public affairs at the Federation of American Societies for Experimental Biology in Bethesda, Maryland. The federation puts on six large conferences each year that attract a total of around 35,000 participants.

The Keystone study surveyed 1,013 participants from ten conferences, ranging from obesity to the biology of hypoxia. Participants were asked how strongly they agreed with certain statements, such as: "I will leave this conference planning to accelerate publication of some of my data." Nine months later, an e-mail follow-up confirmed whether they had acted as planned.

At the nine-month mark, 90\% of scientists said they had shared information with colleagues at their

\section{"The presumption \\ is that meetings are beneficial, but actual dataare scarce."}

home institutions who had not attended the conference; $60 \%$ had establishedcollaborations or shared information with fellow participants; and almost half had accelerated data publication. Roughly two-thirds of attendees said they had altered the direction of their research based on what they learned at the conference.

At the meetings, $85 \%$ of scientists anticipated that information they gathered would save them time and money in the lab, but only $42 \%$ later reported experiencing such savings. And the savings estimates ranged widely - from 1 week to 2 years and from $\$ 50$ to $\$ 2.5$ million.

Meeting attendees said that conferences that are smalland highly interactive, suchas the Keystone symposia, have particularly highpay-offs compared with larger, more impersonalmeetings.

"The lab canjump ahead by being made aware of new technologies and databases," says Charles Shoemaker, a parasite researcher at Tufts University in North Grafton, Massachusetts.

Pathologist Anjana Rao, at Harvard Medical School in Boston, Massachusetts, organized a 2004 Keystone symposium on cell 
Physicists, meanwhile, are livid over Congress's treatment of the Department of Energy's Office of Science. The office provides the lions share of universities' physics research funding and maintains several large facilities.

The office's research and development budget did creep upwards $0.6 \%$ to $\$ 3.4$ billion, but much of that money will go to congressionally mandated projects, such as a supercomputing centre for Oak Ridge National Laboratory in Tennessee. As a result, several core scientific fields funded by the department face cutbacks.

Hardest hit are the Relativistic Heavy Ion Collider at Brookhaven National Laboratory in Upton, New York, and the CEBAF accelerator at the Thomas Jefferson National Accelerator Facility in Newport News, Virginia. Facing an $8.4 \%$ cut, the facilities may have to slash their operating time by up to $60 \%$, warns Michael Lubell, director of public affairs at the American Physical Society. "Next year the department may have to seriously consider closing one of the two labs," he says.

The National Oceanic and Atmospheric Administration fared a little better, seeing its research budget rise by $2.7 \%$ to $\$ 668$ million. But most of that increase will be earmarked for an Alaskan fisheries programme. The National
Institute of Standards and Technology saw its research budget drop by the same percentage, to $\$ 448$ million. And its programme to fund high-risk research barely survived White House attempts to eliminate it, as the research budget for the Advanced Technology Program was slashed $43 \%$ to $\$ 65$ million.

In July, Congress passed budgets for agencies including the Environmental Protection Agency and the US Geological Survey - both of which got tiny research increases that do not
compensate for inflation. And "This is not the final October saw Congress slow the Department of Homeland Security's research budget to an increase of $4.1 \%$ after several years of explosive growth.

Lawmakers will now turn their attention to finishing the final budget bills, which will set funding for agencies such as the National Institutes of Health and the Department of Defense.

On top of these numbers, all federal agencies are expecting an across-the-board cut of $2 \%$ or more to help pay for military and disaster spending. ${ }^{\alpha}$ This is not the final number, says Caroline McGuire, of the lobby group Lewis-Burke Associates in Washington DC. "There's another shoe to drop."

Geoff Brumfiel and Tony Reichhardt signalling. She notes that a team of researchers might save up to $\$ 20,000$ by learning that a group at another laboratory had already developed a mouse model that couldbeuseful in their research.

Researchers say it is difficult to quantify the exact benefits accrued by conferences. "How do you add all of it up to a precise number?" asks

Shoemaker. "Youcan't. But it's big, and it's real."

Kendall Powell 